\title{
LATIHAN HIGH INTENSITY PLYOMETRIC HURDLE HOPPING MENINGKATKAN KEMAMPUAN VERTICAL JUMP SPIKER
}

\author{
Herwin $^{1}$, Imam Subadi ${ }^{2}$, dan Purwo Sri Rejeki ${ }^{3}$ \\ 1,3Prodi Magister Ilmu Kesehatan Olahraga Fakultas Kedokteran Unair \\ ${ }^{2}$ Departemen Kedokteran Forensik dan Rehabilitasi Medik Fakultas Kedokteran Unair \\ ${ }^{2}$ Lab/SMF ${ }^{2}$ Departemen Kedokteran Forensik dan Rehabilitasi Medik RSUD Dr.Soetomo \\ ${ }^{2} \mathrm{Lab} / \mathrm{SMF}{ }^{2}$ Departemen Kedokteran Forensik dan Rehabilitasi Medik RS Unair \\ ${ }^{3}$ Departemen Fisiologi Fakultas Kedokteran Unair \\ Email: herwin.s.pd@gmail.com
}

\begin{abstract}
Abstrak. Keterampilan teknik spike membutuhkan kemampuan vertical jump yang baik. Penelitian ini bertujuan untuk mengetahui perbedaan kemampuan vertical jump setelah melakukan latihan high intensity plyometric hurdle hopping pada pemain bolavoli. Metode penelitian menggunakan metode eksperimen lapangan dengan one group pretest-posttest design. Sembilan sampel atlet dipilih dari populasi atlet bolavoli klub pertamina Makassar secara random. Vertical jump test digunakan untuk mengukur tinggi lompatan. Sampel berpartisipasi dalam penelitian tiga hari dalam seminggu selama empat minggu dan menyelesaikan 12 sesi pelatihan, pada frekuensi 3 sesi per minggu. Hasil paired $t$-test menunjukkan perbedaan yang signifikan pada kemampuan tinggi lompatan $(\mathrm{p}<0,05)$. Disimpulkan dari penelitian ini bahwa pelatihan high intensity plyometric hurdle hopping meningkatkan kemampuan vertical jump pemain bolavoli.
\end{abstract}

Kata Kunci: plyometric, hurdle hopping, tinggi lompatan.

\section{PENDAHULUAN}

Spike merupakan keterampilan bermain yang paling sering menghasilkan poin dalam permainan bolavoli (Putra, 2015). Penelitian robbah (2018) membuktikan bahwa spike tim japan melawan kazakhtan pada final Asean Volleyball Championship mencapai $85 \%$ dalam memperoleh poin. Sedangkan Patsiaouras, et al (2012) menyatakan bahwa total attack pada pertandingan putra Olympic Games of Beijing 2008 mencapai 96,5\%.

Spike merupakan pukulan serangan bolavoli yang keras dari atas ke bawah dengan jalan bola menukik (Nuril, 2007). Keberhasilan spike dipengaruhi oleh tinggi dan kecepatan lompatan (Vassil and Bazanov, 2012), sehingga diperlukan metode latihan khusus untuk meningkatkan kecepatan kemampuan melompat vertical atlet (Harmandeep et al., 2015).

Saat ini telah banyak dikembangkan berbagai macam metode latihan untuk meningkatkan vertical jump salah satunya adalah latihan plyometric (Pamungkas, 2016). Namun, hal ini masih menjadi perdebatan di kalangan pelatih dan peneliti mengenai bentuk plyometric yang lebih efektif untuk peningkatan vertical jump.

Latihan plyometric hurdle hopping intensitas rendah (Vassil and Bazanov, 2012) belum menunjukkan perbedaan yang signifikan, sedangkan pada intensitas sedang (Kalfi, 2013) memberikan peningkan kemampuan vertical jump. Namun, latihan plyometric hurdle hopping intesitas tinggi belum di uji dan perlu dilakukan penelitian untuk metode terbaru dalam 
meningkatkan kemampuan vertical jump.

\section{METODE}

Jenis penelitian yang dilakukan adalah eksperimental lapangan dengan desain one group pretest - posttest. 9 atlet dipilih sebagai sampel penelitian dari populasi atlet bolavoli klub pertamina Makasar berdasarkan rumus lemeshow (1997). Pemilihan sampel dilakukan secara random berdasarkan kriteria inklusi, yaitu atlet laki-laki sehat klub bolavoli pertamina Makassar, Usia 17-28 tahun, tinggi badan 163-185 cm, berat badan $60-80 \mathrm{Kg}$, dan memiliki IMT normal $\left(18,5-22,9 \mathrm{~kg} / \mathrm{m}^{2}\right)$.

Intervensi latihan high intensity plyometric hurdle hopping diberikan dengan frekuensi 3 kali per minggu selama 4 minggu. Vertical jump test digunakan sebagai instrumen pengumpul data tinggi lompatan. Teknik analisis data menggunakan uji deskriptif, Shapiro wilk, levene test, dan paired ttest dengan bantuan program SPSS 17 .

Tabel 1. Program Latihan High Intensity Plyometric Hurdle Hopping

\begin{tabular}{|c|c|c|c|c|c|c|c|}
\hline $\begin{array}{c}\text { Latihan } \\
\text { ke }\end{array}$ & $\begin{array}{c}\text { Minggu } \\
\text { ke }\end{array}$ & Hari & $\begin{array}{l}\text { Jumlah } \\
\text { hurdle }\end{array}$ & $\begin{array}{l}\text { Tinggi } \\
\text { hurdle } \\
\text { (cm) }\end{array}$ & Repetisi & Set & $\begin{array}{c}\text { Interval } \\
\text { istirahat } \\
\text { antar set } \\
\text { (menit) }\end{array}$ \\
\hline 1 & \multirow{3}{*}{ I } & Senin & 6 & 40 & 15 & 3 & 2 \\
\hline 2 & & Rabu & 6 & 40 & 15 & 3 & 2 \\
\hline 3 & & Jumat & 6 & 40 & 15 & 3 & 2 \\
\hline 4 & \multirow{3}{*}{ II } & Senin & 7 & 45 & 15 & 3 & 2 \\
\hline 5 & & Rabu & 7 & 45 & 15 & 3 & 2 \\
\hline 6 & & Jumat & 7 & 45 & 15 & 3 & 2 \\
\hline 7 & \multirow{3}{*}{ III } & Senin & 8 & 50 & 16 & 4 & 2 \\
\hline 8 & & Rabu & 8 & 50 & 16 & 4 & 2 \\
\hline 9 & & Jumat & 8 & 50 & 16 & 4 & 2 \\
\hline 10 & \multirow{3}{*}{ IV } & Senin & 8 & 55 & 16 & 4 & 2 \\
\hline 11 & & Rabu & 8 & 55 & 16 & 4 & 2 \\
\hline 12 & & Jumat & 8 & 55 & 16 & 4 & 2 \\
\hline
\end{tabular}

\section{HASIL DAN PEMBAHASAN}

Analisa deskriptif memberikan gambaran data pengukuran tinggi lompatan berdasarkan nilai minimal, maksimal, rerata dan simpangan baku. Analisa deskriptif meliputi data pre-test dan post-test hasil vertical jump test.

\section{Tabel 2. Analisa deskriptif}

\begin{tabular}{lcc}
\hline Variabel & Pre test & Post test \\
\hline Nilai tertinggi & 79 & 84 \\
\hline Nilai terendah & 42 & 45 \\
\hline Rerata & 61,78 & 65,67 \\
\hline Simpangan baku & 10,952 & 11,380 \\
\hline
\end{tabular}


Berdasarkan tabel 2, terdapat peningkatan rerata tinggi lompatan 3,89 $(6,29 \%)$ dengan perbedaan nilai tertinggi 5 dan nilai terendah 3 . Selanjutnya dilakukan uji Shapiro wilk dan levene test sebagai uji persyaratan sebelum melakukan uji hipotesis secara parametrik atau non-parametrik.

Tabel 3. Uji Normalitas-Homogenitas

\begin{tabular}{ccc}
\hline Uji & Pre test & Post test \\
\hline $\begin{array}{c}\mathrm{p} \text { (sig) } \\
\text { shapiro wilk }\end{array}$ & 0,892 & 0,944 \\
\hline Keterangan & Normal & Normal \\
\hline $\begin{array}{c}\mathrm{p} \text { (sig) levene } \\
\text { test }\end{array}$ & 0,052 & 0,092 \\
\hline Keterangan & Homogen & Homogen \\
\hline
\end{tabular}

Berdasarkan tabel 3, data tinggi lompatan pre-test - post-test memiliki distribusi normal dan homogen ( $\mathrm{p}>$ 0,05 ), sehingga selanjutnya uji hipotesis dilakukan secara parametrik melalui paired t-test. Paired t-test merupakan uji statistik parametrik untuk mengetahui pengaruh intervensi latihan high intensity plyometric hurdle hopping.

Tabel 4. Uji Hipotesis

\begin{tabular}{cccc}
\hline & Variabel & $\begin{array}{c}\text { Paired } \\
\text { t-test }\end{array}$ & $\begin{array}{c}\mathrm{p} \\
(\mathrm{sig})\end{array}$ \\
\hline $\begin{array}{c}\text { Latihan } \\
\text { high }\end{array}$ & & & \\
$\begin{array}{c}\text { intensity } \\
\text { plyometric } \\
\text { hurdle }\end{array}$ & $\begin{array}{c}\text { Tinggi } \\
\text { hopping }\end{array}$ & $\begin{array}{c}\text { Pretest- } \\
\text { posttest }\end{array}$ & 0,000 \\
\hline
\end{tabular}

Berdasarkan tabel 4, intervensi latihan high intensity plyometric hurdle hopping selama 4 minggu dengan frekuesnsi $3 \mathrm{kali} /$ minggu memberikan perbedaan yang signifikan pada tinggi lompatan atlet bolavoli ( $\mathrm{p}<0,05)$.

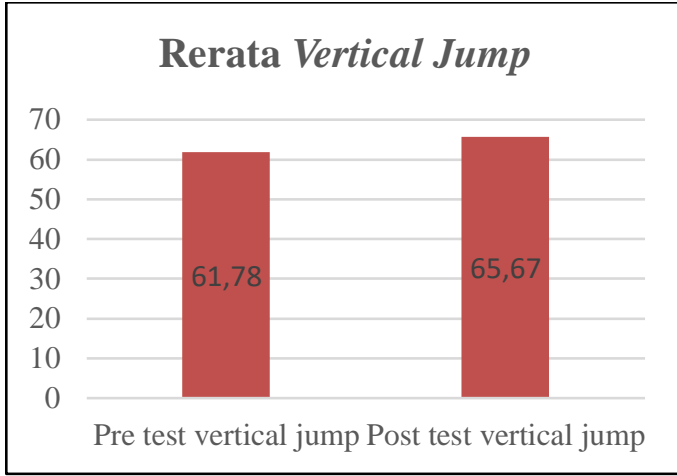

Gambar 1. Diagram Batang Rerata Vertical Jump

Berdasarkan gambar 1 menunjukkan bahwa rerata pretest vertical jump yaitu 61.78, sedangkan rerata posttest vertical jump menunjukkan peningkatan setelah diberikan perlakuan berupa latihan high intensity hurdle hopping menjadi 65.67.

\section{PEMBAHASAN}

Tabel 4 menunjukkan bahwa latihan high intensity plyometric hurdle hopping lebih meningkatkan vertical jump. Hasil yang didapatkan ini hampir sama dengan penelitian terdahulu oleh Pamungkas (2016) bahwa latihan high intensity plyometric hurdle hopping berpengaruh terhadap tinggi loncatan pada atlet bola voli. Latihan high intensity plyometric hurdle hopping meningkatkan vertical jump kemungkinan dikarenakan hasil dari latihan high intensity plyometric hurdle hopping dapat meningkatan daya ledak dan kekuatan kontraksi sehingga hal tersebut berpengaruh terhadap peningkatan vertical jump. Latihan plyometric adalah gerakan dari rangsangan peregangan otot secara mendadak supaya terjadi kontraksi yang lebih kuat. Latihan tersebut dapat menghasilkan peningkatan daya ledak dan kekuatan kontaksi. Daya ledak dan kekuatan kontaksi otot merupakan cermin peningkatan adaptasi fungsional neuromuscular. Peningkatan kontraksi otot merupakan perbaikan fungsi reflek 
peregangan dari muscle spindle. Berdasarkan penjelasan tersebut bahwa latihan plyometric adalah bentuk metode latihan untuk meningkatkan daya ledak otot dengan bentuk kombinasi latihan isometrik dan isotonik (eksentrikkonsentrik) yang menggunakan pembebanan dinamik. Regangan yang terjadi secara mendadak sebelum otot berkontraksi kembali atau suatu latihan yang memungkinkan otot-otot untuk mencapai kekuatan yang maksimal dalam waktu yang sesingkat mungkin. Selain itu pola gerakan plyometric sebagian besar mengikuti konsep power chain (rantai power) yang sebagian besar melibatkan otot pinggul dan tungkai. Gerakan kelompok otot pinggul dan tungkai merupakan pusat power yang memiliki keterlibatan yang besar dalam semua gerakan dalam olahraga (Susilawati, 2018).

Power merupakan kemampuan otot untuk mengerahkan kekuatan maksimal dalam waktu yang sangat cepat untuk mengatasi beban atau tahanan dengan kecepatan kontraksi yang tinggi. Dalam lompatan, yang berperan adalah kekuatan otot tungkai karena merupakan tumpuan dan menunjang dorongan untuk mengangkat seluruh badan ke atasmelayang di udara (Hidayat, Saichudin, \& Kinanti, 2017). Serta latihan high intensity plyometric hurdle hopping juga dapat mengembangkan kekuatan otot kaki karena latihan ini mengandalkan kekuatan kaki "yang mana kaki harus terus melompat-lompat melompati rintangan yang ada didepan secara berturut-turut dengan beberapa pengulangan (Susilawati, 2018). Menurut Behrens et al., (2016) latihan plyometric dapat meningkatkan aktivasi otot volunter dengan menginduksi adaptasi spesifik di tingkat supraspinal (tulang belakang) tergantung pada mode kontraksi. Peningkatan ketinggian lompatan mungkin merupakan akibat dari adaptasi saraf. Adaptasi saraf ini melibatkan peningkatan frekuensi penembakan dan pengerahan $\alpha$ motoneuron. Hal ini dikarenakan latihan plyometric menyebabkan peregangan otot yang cepat (aksi eksentrik) dan pemendekan cepat (aksi konsentris) (Johnson et al., 2011). Energi elastis yang tersimpan dalam otot selama peregangan digunakan untuk menghasilkan lebih banyak kekuatan mengikuti fase konsentris. Latihan plyometric dapat memfasilitasi perifer dan adaptasi saraf pusat yang meningkatkan sendi proprioception dan kesadaran kinestetik. Aktivitas quick stretch dan shortening dapat menyebabkan sensitivitas dari spindel otot dan desensitisasi organ tendon golgi selama pembebanan eksentrik (Swanik et al., 2002).

\section{KESIMPULAN}

Latihan high intensity plyometric hurdle hopping selama 4 minggu dengan frekuesnsi 3 kali/minggu meningkatkan kemampuan vertical jump pemain bolavoli.

\section{DAFTAR PUSTAKA}

Behrens, M., Mau-Moeller, A., Mueller K, Heise S, Gube, M., Beuster, N., Bruhn S. Plyometric training improves voluntary activation and strength during isometric, concentric and eccentric contractions.

Journal of Science and

Medicine in Sport, vol. 19 (2): 170-176, 2016.

Harmandeep, Singh. Kumar Satinder, Rathi Amita and Sherawat Anupriya. "Effects of Six Week Plyometrics on Vertical Jumping Ability of Volleyball Players" Department of Physical Education, Guru Nanak Dev 
University, Amritsar, Punjab, India. Research Journal of Physical Education Sciences. ISSN 2320-9011. vol. 3 (4), 1-4, April (2015).

Johnson, B.A., Salzberg, C.L., Stevenson, D.A. A systematic review: Plyometric training programs for young children. Journal of Strength and Conditioning Research, vol. 25 (9): 26232633, 2011.

Kalfi, Rizang. 2013. Pengaruh latihan plyometric hurdle hooping dan depth jump terhadap peningkatan vertical jump atlet bola voli klub Jibs Kids Bantul". Skripsi. Yogyakarta: Universitas Negeri Yogyakarta.

Lameshow S. Besar Sampel dalam Penelitian Kesehatan, Gajah Mada University Press, Yogyakarta, 1997.

Nuril, Ahmadi. Panduan Olahraga Bolavoli. Yogyakarta: Universitas Negeri Yogyakarta: EraPustaka Utama, 2007.

Pamungkas, Kejora Puteri. Pengaruh Penambahan Electrical Myostimulation (EMS) dan Latihan Hurdle Hops Terhadap Tinggi Lompatan, 2016.

Patsiaouras, A., Moustakidis, A., Charitonidis, A., Kokaridas, D. Technical Skills Leading in Winning or Losing Volleyball Matches During Beijing Olympic Games. Journal of Physical Education and Sport, vol. 11 (2): 149 -152, 2011.

Pritama, M.A., Sugiharto, Rahayu, S. Pengaruh Metode Latihan Smash dan Koordinasi Mata Tangan dengan Menggunakan
Umpan Langsung dan Tak

Langsung Umpan Pada

Bulutangkis. Journal of Physical

Education and Sport, vol. 3 (1): 46-50. Psikologi, 2 (2): 54-66, 2014 .

Robbah, Ahmad. Analisis Keterampilan Pemain Pada Hasil Statistika Tim Finalis Asean Volleyball Championship Putra 2017. Surabaya: Skripsi, 2018.

Sudarmanto, E., Supriyadi, A.P., Hakiki, M.I. Journal of Soprt Science and Education (JOSSAE), vol. 3 (2): 60-68, 2018.

Suharno. Metodik Melatih Permainan Bola Volley. Yogyakarta: IKIP Yogyakarta, 1981.

Susilawati, N. Pengaruh Latihan plyometric Hurdle Hopping Terhadap Kemampan Daya Ledak Otot Tungkai. Jurnal Pendidikan Jasmani dan Olahraga, vol. 17 (1): 29-34, 2018.

Swanik, K.A., Lephart, S.M., Swanik, C.B., Lephart, S.P., Stone, D.A., $\mathrm{Fu}$, F.H. The effects of shoulder plyometric training on proprioception and selected muscle performance characteristics. Journal of Shoulder Elbow Surgery, vol. 11(6): 579-586, 2002.

Vassil, Karin and Boris Bazanovk., 2012. "The effect of plyometric training program on young volleyball players in their usual training Period" Journal of Human Sport and Exercise. January 2012. Institute of Health Sciences and Sports, Tallinn University Estonia. 